\title{
Um estudo sobre os processos de Monotongação e Ditongação no português do Brasil
}

\section{Lucas Pereira Eberle*, Maria Filomena Spatti Sândalo.}

\section{Resumo}

Este é um estudo na área de fonologia e tem como questões a monotongação de ditongos através do apagamento do glide e a ditongação causada pela epêntese de [j] em sílabas tônicas com /S/ na coda. Fizemos um estudo experimental e acústico com modelagem na Teoria da Otimalidade usando o programa MaxEnt Grammar Tool. Trata-se, portanto, de um estudo em linguagem que usa de metodologias experimentais e computacionais em interação.

\section{Palavras-chave:}

ditongação, monotongação, português brasileiro.

\section{Introdução}

Dentro de algumas variantes do Português falado atualmente no Brasil podem se encontrar dois processos fonológicos em andamento, o primeiro em relação à redução de ditongos, como "cadeira" que pode ser dito "cadera" e o segundo, à formação de ditongos em palavras como "mês", por vezes falado "meis". O objetivo deste trabalho é verificar experimentalmente e acusticamente se estes processos ocorrem realmente e quais razões fonético-fonológicas proporcionam ou desfavorecem esse fenômeno.

Investigou-se os fenômenos com base em experimentação e construção de corpora. Para o de monotongação, utilizou-se de e pseudos palavras que fossem compatíveis com o léxico do PB que então foram aplicadas em um teste de julgamento de gramaticalidade. Para o experimento de ditongação, usou-se de palavras existentes no PB que foram gravadas por dois falantes da variedade dialetal de Campinas/SP, após isso foi feita uma análise acústica no programa Praat.

\section{Resultados e Discussão}

Primeiramente, é importa ressaltar que esta pesquisa ainda está em andamento, portanto os resultados apresentados a seguir são parciais.

Os resultados obtidos no experimento de monotongação foram de $64,3 \%$ de palavras aceitas com a redução (301 palavras).

A fidelidade posicional teve certa influência na monotongação, principalmente na questão da monossilabicidade, pois os monossílabos foram os que mais evitaram que a redução acontecesse $(62 \%)$. Diferente das posições iniciais, não iniciais, átonas e tônicas que não demonstraram ter uma influência significativa para o fenômeno até o momento, como mostrado na figura 1.

Desta forma, outro olhar sobre os dados foi necessário. Notou-se que a qualidade das vogais poderia atuar neste processo fonológico, assim como a dispersão entre estas vogais e os glides [j] e [w]. Até o momento, os ditongos que mais evitam a redução são [عw] "éu" $(59,3 \%$ de casos evitados), seguidos de [aj] "ai" e [aw] "au" (ambos com $48,9 \%)$.

É interessante notar que estes três ditongos possuem dispersão intermediária em relação aos outros, como pode ser observado na figura 2.

A análise do experimento de Ditongação ainda não está tão avançada, mas acredita-se que as propostas de análise apresentadas acima, também se mostrem relevantes.
Figura 1. Porcentagem de cada variável

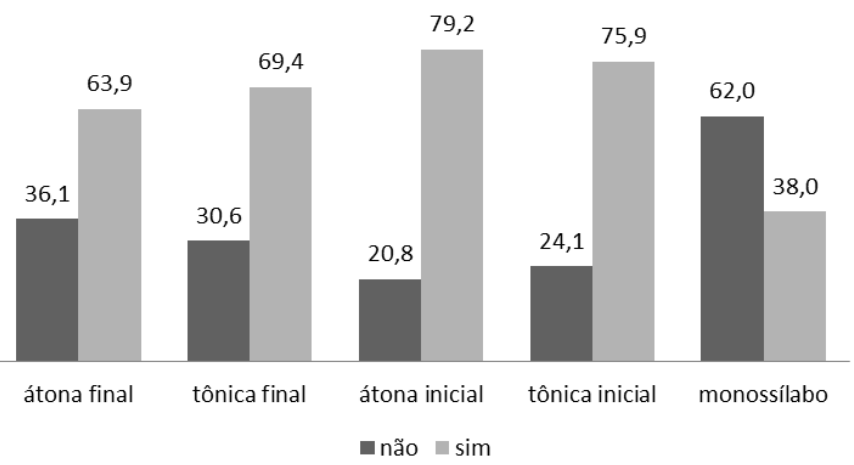

Figura 2. Dispersão dos Ditongos no espaço acústico

\section{Dispersão}

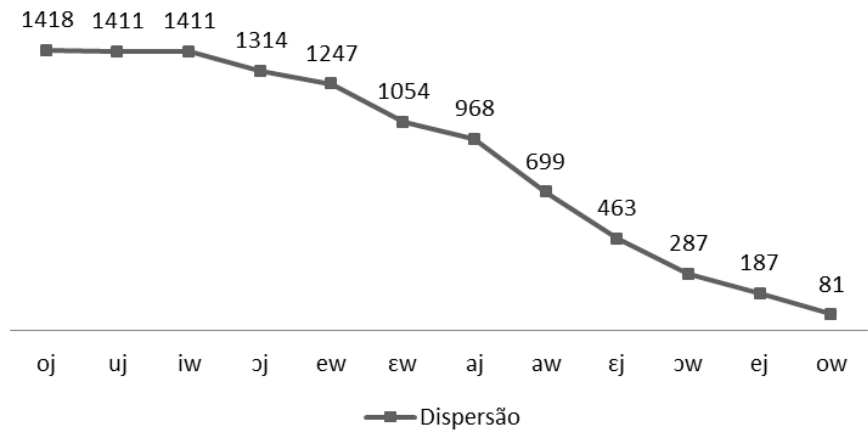

\section{Conclusões}

Ainda é cedo para conclusões, mas já é sabido que a fidelidade posicional teve efeito para a monotongação em relação aos monossílabos, e, espera-se que a dispersão também influencie em ambos os processos.

\section{Agradecimentos}

Agradeço ao $\mathrm{PIBIC/CNPq}$ pelo apoio à ciência e por ter possibilitado a bolsa auxílio ao longo do primeiro semestre de vigência da bolsa, crucial para o desenvolvimento dessa pesquisa.

\footnotetext{
1 BECKMAN, Jill N. Positional faithfulness, positional neutralisation and Shona vowel harmony. Phonology, v. 14, n. 1, p. 1-46, 1997.

${ }^{2}$ NEVINS, Andrew. Enfraquecimento e fortalecimento de vogal em português
} brasileiro. Letras de Hoje, v. 47, n. 3, p. 228-233. 